Bangladesh J. Bot. 47(4): 945-952, 2018 (December)

\title{
EFFECTS OF BIOCHAR ON LEGUME-RHIZOBIUM SYMBIOSIS IN SOIL
}

\author{
Tazeen Fatima Khan* and Md Didar-Ul-Alam \\ Department of Soil, Water and Environment, University of Dhaka, \\ Dhaka-1000, Bangladesh
}

Keywords: Tannery waste, Biochar, Legume, Rhizobium, Cowpea, Food security

\begin{abstract}
An in vitro study was conducted to observe the effects of tannery waste and biochar on soil bacterial population particularly legume-Rhizobium symbiosis. The study comprised a total of seven different treatments including a control. Count of total bacteria and Rhizobium was observed on initial materials and on all treated soils. A leguminous plant, cowpea, was used to study the effects on nitrogen fixation which could be further linked to legume-Rhizobium symbiosis. Bacterial population was higher in tannery waste treated soils than the corresponding biochar treated ones. It was found that waste treated soils had higher Rhizobium count than the biochar treated ones. Nitrogen fixation was found to be higher in tannery waste than biochar treatments. Although there appeared to be no adverse impact on legume-Rhizobium symbiosis, growth of bacteria particularly Rhizobium was inhibited indicating that microbial functioning of the soil might be affected and thereby likely to jeopardize agricultural production and food security.
\end{abstract}

\section{Introduction}

Tannery industry is one of the most important sectors of any country and plays a vital role in national economy. Manufacturers of the industries constitute an indispensable source for export trade and foreign exchange earnings in many developing countries. Being an agro-based byproduct with locally available indigenous raw materials, leather industries possess a potential for export development and sustained growth over the coming years. This industry is the second largest export sector of Bangladesh and currently there are approximately 206 tannery units in Bangladesh (BTA 2010). Of them 114 are large and medium units and the remainders are mostly of small types. About 190 tannery units are located at Hazaribagharea of the capital city, Dhaka covering 60 acres of land (Paul et al. 2013).

About 85,000 tonnes of raw material are processed in Bangladesh annually. Most of the tanneries in Hazaribagh do not have proper effluent treatment plants and generate about $20,000 \mathrm{~m}^{3}$ effluent and 232 tonnes solid waste per day (Paul et al. 2013). About 40 to 50 litres of liquid required for processing each kilogram of hide is poured down in natural canal or low lying areas directly. These untreated solid and liquid wastes find their way into the sewer passing through the area leading to the pollution of water bodies and surrounding environment through destruction of its ecosystem and make the river water unusable (Buljan et al. 2000). Although tannery waste is rich in organic matter they contain significant amounts of chromium, sodium, sulphates, chlorides, inorganic nitrogen, pathogens and toxic compounds which pose serious threats to the microbial functioning of the soil (Sinha et al. 2002).

In the recent years, biochar has been accepted as an immediate, economically viable solution for reducing the global impacts of waste. Biochar, a highly porous and carbon rich product, produced from the waste materials through pyrolysis process, is used to manage waste, improve soil condition, enhance agricultural production that leads to sustainability in environment and reduction in greenhouse gas emissions. Biochar can act as a sorbent for organic and inorganic contaminants and can efficiently remove these waste materials from contaminated sources. Thus, biochar can help to improve food security by contributing to sustainable production systems and

*Author for correspondence: <tazeenkhan18@du.ac.bd>. 
maintaining an eco-friendly environment (Qambrani et al. 2017). However, a big knowledge gap exists about the impacts of biochar on legume-Rhizobium symbiosis in soil. It thus becomes pertinent to assess the response of soil microbes particularly nitrogen fixing Rhizobium bacteria to biochar additions. As a part of this approach, the present study was undertaken to assess the effects of biochar produced from tannery waste on legume-Rhizobium symbiosis and Rhizobium count that could be linked to determine whether biochar brings the same advantages for soil microbes like the waste.

\section{Materials and Methods}

Waste samples were collected from three sites of Hazaribagh tannery area. The first spot was near the main outfall area of Kohinoor Tannery Industries, second spot was about 500 meters and third spot was nearly about one kilometer away from the first spot. The geo-references of the sampling spots are $23.738961^{\circ} \mathrm{N}$ and $90.367615^{\circ} \mathrm{E}, 23.846167^{\circ} \mathrm{N}$ and $90.243324^{\circ} \mathrm{E}, 23.845982^{\circ} \mathrm{N}$ and $90.242906^{\circ} \mathrm{E}$, respectively. The surface soil $(0-15 \mathrm{~cm}$ depth) of Chandina Series was used as a control. The depth of the soil was decided to represent the rhizosphere as legume-Rhizobium symbiosis was to be observed. According to USDA soil classification, the soil belongs to loamy, mixed, non-acid and the soil taxonomy is Aeric Haplaquept (Rahman 2005).

Sampling containers with proper labeling were used to collect waste and soil samples. Collection of soil samples was done by following composite sampling techniques as suggested by the USDA (1951). Collected samples were dried in air (at $\sim 40^{\circ} \mathrm{C}$ ) followed by removing visible roots and debris. Larger samples were broken down and screened through $2 \mathrm{~mm}$ sieve which will be used for various physical analysis. Another portion of the sample was screened through $0.5 \mathrm{~mm}$ sieve which will be used for chemical analysis. The bulk soil samples collected for pot experiment were air-dried, cleared-off the debris and crushed to make the bigger clods smaller which were then screened through $5 \mathrm{~mm}$ sieve (Carter and Gregorich 2007). Solid waste samples were air dried, ground and sieved through $0.2 \mathrm{~mm}$ sieve to assess physicochemical properties of these samples. For microbiological analysis, collected samples were kept in cool and dark place so that the sample does not deteriorate and the analytical results were representative.

A big earthen pot was taken and metal wires were arranged in a criss-cross arrangement in such a way that pots were uniformly heated from all sides. Tannery wastes were placed layer by layer in small earthen pots. These pots were covered with earthen lids. Finally, fire was lighted and accelerated by adding kerosene oil. After about an hour, when the waste was turned to biochar, fire was stopped. After cooling of the biochar, lids of the pots were opened and screened through $0.25 \mathrm{~mm}$ sieve (Khan et al. 2014).

Physical, chemical and physico-chemical properties of the soil, waste and biochar samples were analyzed by the standard procedures described by Hesse (1972). For every ten samples a Certified Reference Material (CRM) was included to ensure quality control/quality assurance (QC/QA).

In order to assess the impact of biochar on legume-Rhizobium symbiosis, a pot experiment was carried out with cowpea (Vigna sinensis). Tannery waste and biochar produced from the corresponding waste were mixed with Chandina soil at $5 \mathrm{t} / \mathrm{ha}$. A total of 21 plastic pots including control were arranged in a completely randomized design. The seven treatments were designated as T0, T1, T2, T3, T4, T5 and T6 (Table 1).

Pour plate technique was followed as described by Khan and Huq (2014) for determining Total Viable Count (TVC) of bacteria which were expressed by the number of Colony Forming Units per gram of soil (CFU/gm). 
The soil was sterilized at $120^{\circ} \mathrm{C}$ for $48 \mathrm{hrs}$ after the treatments were applied (Goldman and Green 2008). After that, soil was cooled down and soaked with sterilized deionized water. Surface sterilized (with $0.5 \%$ potassium hypochlorite) certified seeds of cowpea were sown in the pots. After germination of seven days, purified Rhizobial strain was added to the rhizosphere of the seedlings. Each pot was watered with sterilized deionized water. Plants were harvested manually after 60 days by uprooting the plant carefully from the pot. Soil samples were also collected after harvesting. Collected plant samples were first air-dried and then oven-dried at $70 \pm 5^{\circ} \mathrm{C}$ for $48 \mathrm{hrs}$. Both fresh and dry weight of plants was measured. The dried plant samples were then ground, mixed thoroughly and stored for further laboratory analysis. Plant samples were digested with $\mathrm{H}_{2} \mathrm{SO}_{4}$ and $\mathrm{N}$ content was determined by alkali distillation of the Kjeldahl digests (Jackson 1962).

Table 1. Design of the pot experiment and used symbols.

\begin{tabular}{lcc}
\hline \multicolumn{1}{c}{ Treatment } & Rate of application & Symbol \\
\hline Control & $5 \mathrm{t} / \mathrm{ha}$ & $\mathrm{T} 0$ \\
\hline Soil + waste of $1^{\text {st }}$ spot & $5 "$ & $\mathrm{~T} 1$ \\
Soil + waste of $2^{\text {nd }}$ spot & $5 "$ & $\mathrm{~T} 2$ \\
Soil + waste of $3^{\text {rd }}$ spot & $5 "$ & $\mathrm{~T} 3$ \\
Soil + biochar from waste of $1^{\text {st }}$ spot & $5 "$ & $\mathrm{~T} 4$ \\
Soil + biochar from waste of $2^{\text {nd }}$ spot & $5 "$ & $\mathrm{~T} 5$ \\
Soil + biochar from waste of $3^{\text {rd }}$ spot & $5 "$ & $\mathrm{~T} 6$ \\
\hline
\end{tabular}

Healthy and unbroken root nodules from each of treatment soils were randomly selected for isolation of Rhizobia following the method described by Somasegaran and Hoben (1985). Nodules were surface disinfected by immersion in ethanol $(95 \% \mathrm{v} / \mathrm{v})$ followed by immersion in $3.8 \%$ sodium hypochlorite and finally rinsed with sterile double-distilled water. The nodules were crushed in $100 \mu \mathrm{l}$ of sterile distilled water using a sterilized blunt forceps. One loopful of each nodule suspension was aseptically streaked onto YEMA ( $10 \mathrm{~g}$ mannitol, $0.2 \mathrm{~g} \mathrm{MgSO}_{4} \cdot 7 \mathrm{H}_{2} \mathrm{O}, 0.2 \mathrm{~g}$ $\mathrm{NaCl}, 0.5 \mathrm{~g} \mathrm{~K}_{2} \mathrm{HPO}_{4}, 1 \mathrm{~g}$ yeast extract, and $15 \mathrm{~g}$ agar) agar medium containing bromothymol blue having $\mathrm{pH}$ of $6.8 \pm 0.2^{\circ} \mathrm{C}$. The plates were then incubated at $28^{\circ} \mathrm{C}$ and observed periodically to characterize colony growth.

After incubation of 10 days, distinct colonies of Rhizobia started to appear as described in Somasegaran and Hoben (1985). Presence of Rhizobium was confirmed by observing morphological characteristics of the colonies and finally viable count was done manually. All microbiological experiments were conducted in aseptic condition, which prevented contamination and assured accuracy of result. The experimental data were statically analyzed by using the Microsoft Excel (version 2016) and MINITAB (version 18).

\section{Results and Discussion}

The soil, tannery waste and biochar were analyzed to determine their nutritional status and heavy metal contents. It was found that Chandina soil was silty loam in texture and slightly acidic in character ( $\mathrm{pH}$ 6.73). Its content of organic matter, total nitrogen, CEC and EC was $1.12 \%$, $0.11 \%, 37.90 \mathrm{meq} / 100 \mathrm{~g}$ and $1.01 \mathrm{dS} / \mathrm{m}$, respectively. Contents of heavy metals viz., Fe, Mn, $\mathrm{Zn}$ and $\mathrm{Cu}$ were 24178, 381, 235 and $130 \mathrm{ppm}$, respectively. Contents of $\mathrm{Cr}$ and $\mathrm{Cd}$ were found to be negligible. Basic chemical properties of the tannery waste samples collected from three different spots and their corresponding biochars are presented in Table 2 . 
When the tannery waste turned into biochar, its properties changed. In almost all of the cases, values of $\mathrm{pH}, \mathrm{EC}$ and organic matter increased. Contents of organic matter were almost doubled. Similar trend was also observed in case of heavy metal contents. Heavy metals viz., $\mathrm{Fe}, \mathrm{Cu}, \mathrm{Cr}$ and $\mathrm{Cd}$ were found to increase from waste to biochar. On the contrary, no significant change was observed for Mn and Zn. Khan et al. (2015) observed that contents of heavy metal increased when biomass turned to biochar at different incubation periods while working with three types of biomass, namely rice husk, straw and saw dust.

Table 2. Characterization of tannery wastes and biochars.

\begin{tabular}{|c|c|c|c|c|c|c|}
\hline \multirow[b]{2}{*}{ Name of parameter } & \multicolumn{6}{|c|}{ Parameter values of the waste and biochar samples } \\
\hline & $\begin{array}{c}\text { 1st spot } \\
\text { wst }\end{array}$ & $\begin{array}{c}\text { 2nd spot } \\
\text { wst }\end{array}$ & $\begin{array}{c}\text { 3rd spot } \\
\text { wst }\end{array}$ & 1 st spot bc & $\begin{array}{c}\text { 2nd spot } \\
\text { bc }\end{array}$ & $\begin{array}{c}\text { 3rd spot } \\
\text { bc }\end{array}$ \\
\hline $\mathrm{pH}$ & 5.30 & 6.90 & 5.80 & 5.40 & 7.20 & 6.35 \\
\hline $\mathrm{EC}(\mathrm{dS} / \mathrm{m})$ & 6.89 & 5.93 & 6.92 & 7.25 & 5.99 & 7.10 \\
\hline Organic matter $(\%)$ & 16.78 & 13.89 & 12.89 & 35.23 & 27.17 & 24.90 \\
\hline Total N (\%) & 1.89 & 2.01 & 2.02 & 2.05 & 2.05 & 2.08 \\
\hline CEC (meq/100g) & 84.58 & 93.75 & 98.75 & 92.65 & 95.40 & 98.85 \\
\hline Exchangeable $\mathrm{PO}_{4}(\mathrm{ppm})$ & 310.00 & 70.00 & 60.00 & 300.00 & 70.00 & 60.00 \\
\hline Exchangeable K (ppm) & 3200.00 & 980.00 & 175.00 & 3200.00 & 900.00 & 160.00 \\
\hline Exchangeable $\mathrm{SO}_{4}(\mathrm{ppm})$ & 480.00 & 680.00 & 860.00 & 460.00 & 680.00 & 895.00 \\
\hline Exchangeable Ca (ppm) & 815.00 & 760.00 & 895.00 & 810.00 & 750.00 & 895.00 \\
\hline Iron (ppm) & 335.00 & 320.00 & 305.00 & 340.00 & 355.00 & 310.00 \\
\hline Manganese (ppm) & 436.00 & 520.67 & BDL & 435.00 & 510.00 & 35.00 \\
\hline Zinc (ppm) & 280.65 & 265.00 & BDL & 450.00 & 415.00 & 60.95 \\
\hline Copper (ppm) & 75.00 & 65.00 & 63.00 & 120.00 & 95.00 & 110.00 \\
\hline Chromium (ppm) & 35000.00 & 29000 & 20000 & 70000.00 & 60000.00 & 30000.00 \\
\hline Cadmium (ppm) & 5.90 & 6.35 & 1.45 & 10.50 & 15.95 & 3.09 \\
\hline
\end{tabular}

$\mathrm{wst}=$ Waste, $\mathrm{bc}=$ Biochar, $\mathrm{BDL}=$ Below detection limit.

Bacterial colonies started to appear after $24 \mathrm{hrs}$ of incubation indicating the presence of bacteria in these materials. Initially, the soil had Total Viable Count (TVC) of $120 \times 10^{4} \mathrm{CFU} / \mathrm{g}$. Waste of 1 st, 2 nd and $3 \mathrm{rd}$ spot possessed $40 \times 10^{4}, 80 \times 10^{4}$ and $100 \times 10^{4} \mathrm{CFU} / \mathrm{g}$ of TVC, respectively. T3 had more viable count which could be due to its long distance from the tannery. However, no count was observed in any of the biochar samples. The reason could be that, high temperature for producing char might have killed the microbes that are present in the waste samples. The present findings corroborate with the work of Khan et al. (2014) who showed that most of the microorganisms could not survive when biomass turned to biochar due to its antagonistic effects resulting from nutrients deficiency, decreased sorption of enzymes and formation of complex compounds that are not easily degradable by the microorganisms.

Fig. 1 shows that the highest bacterial population was in $\mathrm{T} 3$ as indicated by the highest number of TVC $\left(70 \times 10^{4} \mathrm{CFU} / \mathrm{g}\right)$. Conversely, the lowest bacterial population was found in T4 and T5 $\left(25 \times 10^{4}\right)$. It was observed that soil treated waste treatments (T1, T2 and T3) contained less bacteria than that of the control soil (T0). It might be due to the high concentrations of salt and heavy metal present in tannery wastes. Moreover, after applying the biochar treatments, bacterial population was decreased from both the waste treated soil and control soil. De Luca and Gundale (2006) observed that biochar participated in rapid mineralization of labile carbon leading to 
reduced soil nitrogen that led to decreased availability of total $\mathrm{N}$ and $\mathrm{C}$ for the microbes. Although no bacterial growth was observed in initial biochar materials produced from tannery wastes, growth appeared after mixing with the soil. Dioselina et al. (2006) found that effluents from leather processing tannery industries contains valuable nutrients as well as contaminants, particularly salts and $\mathrm{Cr}$, that might affect soil processes and crop production. They revealed that untreated tannery waste increased soil organic matter and microbial biomass $\mathrm{C}$ while $\mathrm{C}$ mineralization and $\mathrm{N}$ mineralization remained low. AVOVA test indicates that both treatment and $\mathrm{pH}$ had highly significant effect $(\mathrm{p}=0.000)$ on TVC. In all three cases the waste and biochar treatments showed significant differential effect on TVC.

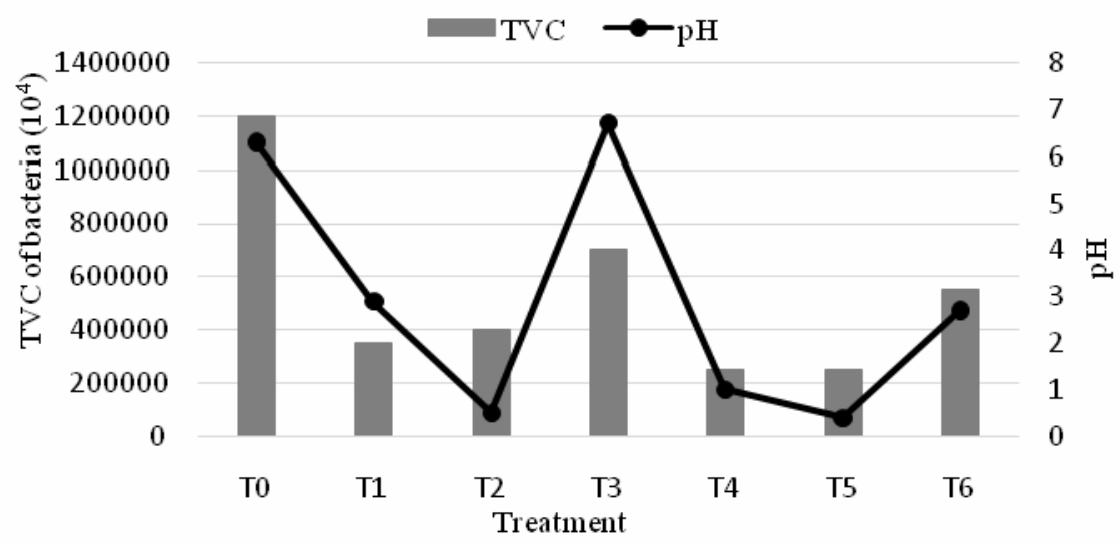

Fig. 1. Relationship between bacterial population and $\mathrm{pH}$ affected by different treatments.

The cowpea did not show any visual symptoms of toxicity after 20 days of germination grown in tannery waste treated soils. However, at the later stage, plant growth rate decreased and chlorosis was observed. On the other hand, biochar treated soil showed visual symptoms after 15 days of germination which might indicate toxicity or deficiency. Yellow spot was observed, which eventually spread throughout the whole plant. Growth of plant was reduced followed by chlorosis, stunting, reduced branching and abnormal darkening. Stems and lower leaf surfaces of the plants turned to purple grown on $\mathrm{T} 4$.

Table 3 shows that fresh and dry matter contents of cowpea were lower in biochar treated soil than those of the waste treated and control soil. The LSDs showed significant effect of waste or biochar treatments on the fresh and dry matter production of cowpea as well as amount of fixed $\mathrm{N}$ in plants at 5\% level of significance (Table 3). It is apparent from Table 3 that amount of nitrogen fixation by cowpea was high in control soil $(2433 \mathrm{mg})$ compared to the treatment soils. Among the soils treated with wastes, nitrogen fixation was maximum in T2 $(1639 \mathrm{mg})$ than $\mathrm{T} 1(775 \mathrm{mg})$ and T3 $(880 \mathrm{mg}$ ). It might be due to low contents of heavy metal and high contents of organic matter and nitrogen present in waste of 2 nd spot. High contents of $\mathrm{Zn}, \mathrm{Cd}, \mathrm{Cr}, \mathrm{Cu}$ and Co reduce nitrogen fixation and slow down the activity of Rhizobium (Madariaga and Angle 1991). Araújo et al. (2007) observed the effect of composted textile sludge on growth, nodulation and nitrogen fixation of soybean and cowpea in a greenhouse experiment. They showed that composted textile sludge did not exert any negative effect on nodule number, weight and nodule activity. Zereen et al. (2013) reported that tannery waste water is not suitable for irrigation purpose due to extremely high mineral and heavy metal contents. They mentioned that the effluent is highly alkaline with high values of Fe, Mn, Zn, Cr, EC, BOD, COD and SAR which leads to reduced growth and yield of plants. 
It was observed that nitrogen fixation in the soils treated with tannery waste is lower than that of the corresponding biochar treated ones except T2. In the present study, among the biochar treatments, maximum $\mathrm{N}$ was fixed in T6 $(2476 \mathrm{mg})$ and minimum in T5 $(12 \mathrm{mg})$, because T6 was the farthest spot from the tannery industry whereas T5 was collected from the vicinity of the discharging site. Chowdhury et al. (2015) noted that pollution from the effluents of leather processing tannery industries decreases with distance.

Table 3. Fresh and dry matter content of cowpea and amount of fixed nitrogen at different treatments.

\begin{tabular}{lcccc}
\hline Treatment & $\begin{array}{c}\text { Fresh weight } \\
\text { (g/plant) }\end{array}$ & $\begin{array}{c}\text { Dry weight } \\
\text { (m/plant) }\end{array}$ & $\begin{array}{c}\text { Amount of N in 100 } \\
\text { plants (mg) }\end{array}$ & $\begin{array}{c}\text { Amount of N fixed } \\
\text { by 100 plants (mg) }\end{array}$ \\
\hline T0 & 8.08 & 0.97 & 2813 & 2433 \\
T1 & 2.36 & 0.33 & 1155 & 775 \\
T2 & 5.07 & 0.66 & 2019 & 1639 \\
T3 & 3.46 & 0.45 & 1260 & 880 \\
T4 & 3.08 & 0.37 & 1180 & 800 \\
T5 & 0.21 & 0.07 & 392 & 12 \\
T6 & 6.0 & 0.84 & 2856 & 2476 \\
LSD (at 5\%) & 0.00 & 0.00 & 0.00 & 0.00 \\
\hline
\end{tabular}

Following incubation at $28^{\circ} \mathrm{C}$ for 10 days, distinct colonies of Rhizobium were identified based on their size (2 to $4 \mathrm{~mm}$ ), color (white), shape (round, ellipsoid, irregular) and elevation (raised, flattened). Under microscope they were observed as short rod. Initially, the viable count of Rhizobium in the soil was found to be $60 \times 10^{3} \mathrm{CFU} / \mathrm{g}$. Viable counts of treated soils are presented in Fig. 2. However, no count of bacteria was found in T1. It could be due to the adverse effects of heavy metals present in waste samples. Heavy metals might reduce Rhizobial count by directly affecting its root nodule function, physiology, available $\mathrm{N}$ and plant growth. Studies found that

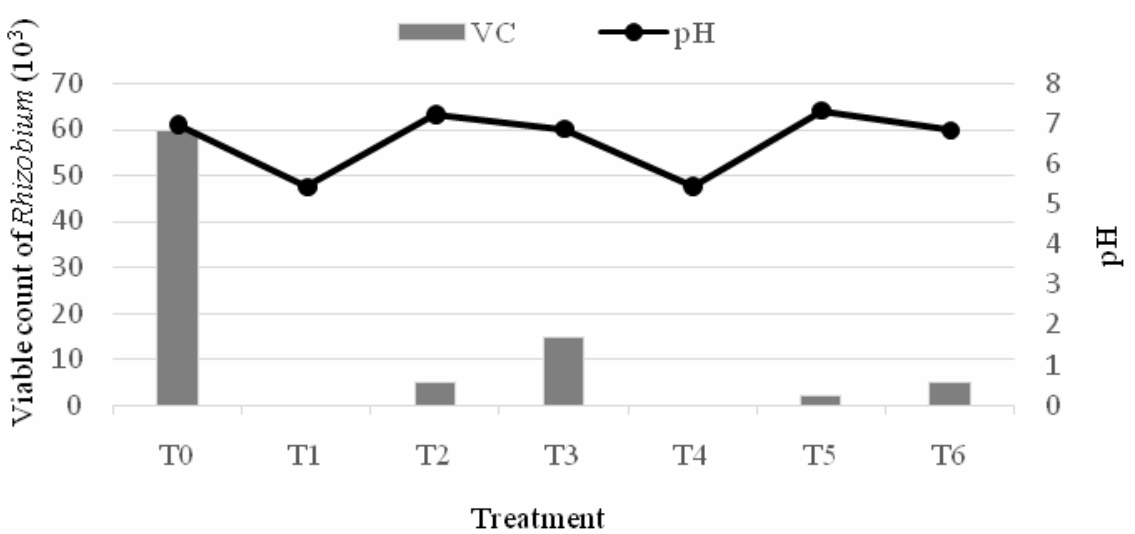

Fig. 2. Relationship between Rhizobium count and $\mathrm{pH}$ affected by different treatments.

heavy metals hampered growth and nodulation of Rhizobium up to a certain limit (Paudyal et al. 2007). As T1 was located near to the tannery industry, its effect was found to be worst on Rhizobium species. Bacterial growth was found to increase in T3 $\left(15 \times 10^{3} \mathrm{CFU} / \mathrm{g}\right)$. In case of biochar treatments, Rhizobium was absent in T4 while it appeared in T5 $\left(2 \times 10^{3} \mathrm{CFU} / \mathrm{g}\right)$ and T6 
$\left(5 \times 10^{3} \mathrm{CFU} / \mathrm{g}\right)$. It was observed that soils with waste treatments had higher bacterial growth than that of corresponding biochar treatments. Khan and Huq (2014) mentioned that Rhizobium are able to use $\mathrm{NH}_{4}{ }^{+}$or $\mathrm{NO}_{3}^{-}$as nitrogen source but when char is added utilization of these compounds might be hampered. Extreme pH hampers nodulation of Rhizobium which leads to reduced growth and population (Mensah et al. 2006). It was revealed in present study that soil alkalinity increased significantly when waste was converted to char (Table 1) which might have adversely affected proliferation of Rhizobium. Moreover, $\mathrm{pH}$ of T1 and T4 was not conducive for the growth of Rhizobium in the laboratory condition as it needs $\mathrm{pH}$ of $6.8 \pm 0.2$. AVOVA test indicates that both treatment and $\mathrm{pH}$ had highly significant effect $(\mathrm{p}=0.000)$ on viable count of Rhizobium. Except for the T2 and T5 $(\mathrm{p}=0.096)$, all waste and biochar treatments showed significant differential effect on viable count.

Although biochar is one of the burning questions of today's modern world to manage waste as well as to maintain soil fertility and ecological resilience, it is not beneficiary with respect to soil microbial population. Both tannery waste and biochar exert adverse effects on soil bacteria, particularly Rhizobium. The effects are much more pronounced for biochar. Biochar produced from tannery waste exerts tremendous negative impacts on the growth and survival of Rhizobium due to the relative stability of biochar and lack of readily utilizable nitrogen sources which might hamper legume-Rhizobium symbiosis. However, no noticeable impact was observed for legumeRhizobium symbiosis although nitrogen fixation was higher in biochar treated soils. It can be concluded that biochar is not a suitable option with respect to soil microbial population. In this context, any potential risks should be thoroughly examined before adopting the biochar due to the irreversibility of applying biochar to agricultural soils.

\section{References}

Araújo AS, Monteiro RT and Carvalho EM 2007. Effect of composted textile sludge on growth, nodulation and nitrogen fixation of soybean and cowpea. Bioresour. Technol. 98(5):1028-32.

BTA (Bangladesh Tanners Association) 2010. Survey Report. 2010, Dhaka, Bangladesh.

Buljan J, Reich G and Ludvik J 2000. Regional programme for pollution control in the tanning industry in South-East Asia. United Nations Industrial Development Organization (UNIDO). Report No. US/RAS/92/120/11-51. pp. 8-15.

Carter MR and Gregorich EG 2007. Soil sampling and methods of analysis. 2nd edition, CRC Press, Boca Raton, Florida . pp. 115-170.

Chowdhury M, Mostafa MG, Biswas TK, Mandal A and Saha AK 2015.Characterization of the effluents from leather processing industries. Envl. Process 2(1): 173-187.

DeLuca TH and Gundale MJ 2006. Temperature and source material influence ecological attributes of Ponderosa Pine and Douglas-Fir charcoal. For. Ecol. Manage 231: 86-93.

Dioselina AB, Silvia MCR, Nieves TT, Victor OP, Frías-Hernández JT and Luc D 2006. Effects of tanneries wastewater on chemical and biological soil characteristics. Appl. Soil Ecol. 33(3): 269-277.

Goldman E and Green LH 2008. Practical handbook of microbiology. 2nd edition. CRC Press, Boca Raton, Florida. pp. 812-840.

Hesse PR 1972. A textbook of soil chemical analysis. Chemical Pub. Co., the University of Michigan, USA. pp. 218-265.

Jackson ML 1962. Soil chemical analysis. Prentice Hall, Inc, Englewood Cliffs, New Jersy. pp. 115-123.

Khan KT, Chowdhury MTA and Imamul Huq SM 2015. Effects of biochar on the fate of heavy metals Cd, $\mathrm{Cu}, \mathrm{Pb}$ and $\mathrm{Zn}$ in soil. Bangladesh J. Sci. Res. 28(1): 17-26.

Khan TF, Ahmed MM and Imamul Huq SM 2014. Effects of biochar on the abundance of three agriculturally important soil bacteria. J. Agri. Chem. Environ. 3: 31-39. 
Khan TF and Imamul Huq SM 2014. Effect of biochar on the abundance of soil bacteria. British Microbiol. Res. J. 4(9): 896-904.

Madariaga GM and Angle JS 1991. Sludge-borne salt effects on survival of Bradyrhizobium japonicum. J. Envl. Qual. 21(2): 276-280.

Mensah JK, Esumeh F, Iyamu M and Omoifo C 2006. Effects of different salt concentrations and pH on growth of Rhizobium sp and a cowpea-Rhizobium association. Amer. Eur. J. Agri. Envl. Sci. 1: 198202.

Paudyal SP, Aryal RR, Chauhan SVS and Maheshwari DK 2007. Effect of heavy metals on growth of Rhizobium strains and symbiotic efficiency of two species of tropical legumes. Sci. World 5(5): 27-32.

Paul HL, Antunes APM , Covington AD , Evans P and Phillips PS 2013. Bangladeshi leather industry: an overview of recent sustainable developments. J. Soc. Leather Technol. Chem. 97: 25-32.

Qambrani NA, Rahman MM, Seunggun W, Shim S and Ra C 2017. Biochar properties and eco-friendly applications for climate change mitigation, waste management, and wastewater treatment: A review. Renewable Sustainable Ener. Rev.79: 255-273.

Rahman MR 2005. Soils of Bangladesh. Darpon Publications, Bangladesh. pp 158.

Sinha S, Saxena R and Singh S 2002. Comparative studies on accumulation of $\mathrm{Cr}$ from metal solution and tannery effluent under repeated metal exposure by aquatic plants: its toxic effects. Environ. Monit. Assess. 80: 17-31.

Somasegaran P and Hoben HJ 1985. Methods in legume-Rhizobium technology. University of Hawaii NifTAL Project and MIRCEN, Department of Agronomy and Soil Science, Hawaii Institute of Tropical Agriculture and Human Resources, College of Tropical Agriculture and Human Resources, Paia, Hawaii, USA. pp. 1-52.

United States Department of Agriculture (USDA) 1951. Soil survey manual. Handbook 18. Soil Survey Staff, Bureau of Plant Industry, Soils and Agricultural Engineering, United Sates Department of Agriculture, Washington DC. pp. 313-397.

Zereen A, Wahid A, Khan ZUD and Sardar AA 2013. Effect of tannery wastewater on the growth and yield of sunflower (Helianthus annuus L.) Bangladesh J. Bot. 42(2): 279-285.

(Manuscript received on 24 May, 2018; revised on 4 July, 2018) 